eficial to academic libraries. A request for the proper form should be addressed to the ACRL office.

Members of the ACRL Committee on Grants are: H. Vail Deale, chairman; Humphrey G. Bousfield, consultant; Johnnie E. Givens, Mrs. Virginia Lacy Jones, Rev. Vincent R. Negherbon, Mrs. Jessie Carney Smith, Donald E. Vincent, and David Kaser (ex officio). Any further inquiries should be sent to the Executive Secretary, Association of College and Research Libraries, 50 East Huron Street, Chicago, Illinois 60611 .

\section{AUGMENTED CRL EDITORIAL STAFF}

David Doerrer, assistant circulation librarian, Cornell University, has been named News editor of CRL. Mr. Doerrer will assist David Kaser in the preparation of the monthly $C R L$ News issues. He holds the AB and MSLS degrees from Syracuse University, and is presently writing his thesis for an MA in American history at Syracuse. $\mathrm{He}$ is a former contributor to $C R L$

Mrs. Betty Swint of the Joint University Libraries, Nashville, continues as assistant editor of the bimonthly journal.

Mary Falvey, ACRL publications officer since 1961, on Sept. 1 became managing editor of the Central Production Unit at ALA headquarters. This is a new unit which will be responsible for the production of five journals, six newsletters and other printing and publications for ALA divisions.

\section{MARGARET MANN CITATION}

An annual citation, awarded by the Cataloging and Classification Section of the Resources and Technical Services Division, made to a cataloger and/or classifier, not necessarily an American, for his outstanding professional achievement in the areas of cataloging and classification, either through publication of significant professional literature, participation in professional cataloging associations, introduction of new techniques of recognized importance, or outstanding work in the area of teaching within the past five years.

Deadline for nominations, Dec. 1. Send nominations with resume of achievement on which nomination is based, in triplicate, to the committee chairman-Mrs. Benjamin A. Custer, 9305 Twentieth Avenue, Adelphi, Maryland 20783.

\section{ACRL Membership}

Tuly 31,1968

12,604

July 31,1967

11,915

July 31, 1966

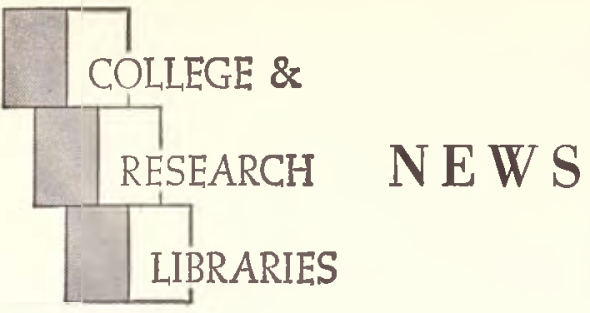

ACRL News Issue of College \& Research Libraries

Editor, David Kaser, Cornell University Libraries, Ithaca, N.Y. 14850.

Managing Editor, Mary Falvey, 50 E. Huron St., Chicago 60611.

News Editor, David Doerrer, Cornell University Libraries, Ithaca, N.Y. 14850.

Editorial Board: John M. DAwson, University of Delaware; Gustave A. Harrer, University of Florida; Samuel Rothstern, University of British Columbia; JAMES E. SkIPPER, University of California, Berkeley; Nomman E. Tanis, Kansas State College of Pittsburg; Mauruce F. Tauner, Columbia University; Emeen Thorston, Oberlin College.

ACRL Officers, 1968/69: President, David Kaser; Chairman, College Libraries Section, Evan Ira Farber; Junior College Libraries Section, Shirley A. Edsall; Rare Books Section, J. M. Edelstein; Subject Specialists Section, Thomas D. Gillies; Agriculture and Biological Sciences Subsection, Louise Darling; Art Subsection, Herbert G. Scherer; Law and Political Science Subsection, Morris L. Cohen; Slavic and East European Subsection, Dmytro M. Shtohryn; University Libraries Section, G. F. Shepherd.

News from the Field, Personnel profiles and notes, classified advertising, official matter of ACRL, and other material of a timely nature is published in the News issues of College \& Research Libraries.

Inclusion of an article or advertisement in $C R L$ does not constitute official endorsement by ACRL or ALA. Production and Advertising and Circulation office: 50 E. Huron St., Chicago, 111. 60611. Change of address and orders for subscriptions should be addressed to College \& Research Libraries, for receipt at the above address, at least two months before the publication date of the effective issue.

Subscription to $C R L$ is included in membership dues to $A C R L$ of $\$ 6$ or more; other subscriptions to $C R L$ are $\$ 10$ per year. Neither subscriptions nor memberships include miscellaneous unscheduled supplements, which are available by purchase only. Retroactive subscriptions are not accepted. Single journal copies are available at $\$ 1.50$ each and News issues at $\$ 1.00$ each from ALA Publishing Department.

Indexed in Library Literature. Abstracted in Library Science Abstracts. Book reviews indexed in Book Review Index.

College \& Research Libraries is the official journal of the Association of College and Research Libraries, a division of the American Library Association; and is published seventeen times per year-bi-monthly as a technical journal with 11 monthly News issues, combining July-August - at 1201-05 Bluff St., Fulton, Mo. 65251

Second-class postage paid at Fulton, Mo. 